\title{
Time Allocation as Correlate of Undergraduates' Academic Achievement in Cataloguing and Classification in Library Schools in Southern Nigeria
}

\author{
Samuel Oke Ogunniyi1, Kenneth Ivo Ngozi Nwalo² \\ ${ }^{1}$ College Library, Adeyemi College of Education, Ondo, Nigeria \\ ${ }^{2}$ Department of Library, Archival and Information Studies, University of Ibadan, Ibadan, Nigeria \\ Email: Samtoyeniyi@Yahoo.Com,kennwalo@yahoo.com
}

Received 1 January 2016; accepted 17 January 2016; published 20 January 2016

Copyright (C) 2016 by authors and OALib.

This work is licensed under the Creative Commons Attribution International License (CC BY). http://creativecommons.org/licenses/by/4.0/

(c) (i) Open Access

\section{Abstract}

The study focuses on time allocation as correlate of undergraduates' academic achievement in cataloguing and classification in library schools in Southern Nigeria. Cataloguing and classification courses are expected to be taught theoretically and practically in library schools. The main problem of this study is undergraduates' poor academic achievement in cataloguing and classification. According to authors, cataloguing and classification are core courses in librarianship. Despite the importance of these courses in the library schools, it is observed that many undergraduates are known to perform poorly in the examinations. Survey research design of correlational type was adopted for this study. Hypothesis tested at 0.05 level of significance was that there was no significant relationship between time allocation and academic achievement of undergraduates in cataloguing in library schools in Southern Nigeria. The 550 final year students and 18 lecturers teaching cataloguing and classification in library schools in Southern Nigeria were purposively selected for the study. Time allocated for teaching and learning cataloguing and classification scale $\mathbf{a}=$ $0.64)$ and students' achievement test in cataloguing and classification $(a=0.63)$ were used to collect data for the study. Descriptive and inferential statistics were used for the data analysis. Results from the study revealed that: there was a significant relationship between time allocation and academic achievement of undergraduates in cataloguing and classification in library schools. Time allocated for teaching cataloguing and classification was inadequate. Academic achievement of the majority of the undergraduates was at average level. The library school management in partnership with the National Universities Commission (NUC) should include separate hour on the time table for practical cataloguing and classification in library schools in Nigeria to enable students to balance theory with practical knowledge. This is necessary to enhance students' academic achievement in cataloguing and classification. Lecturers' teaching cataloguing and classification should spend more time in cataloguing practicals to encourage the students to develop interest in cataloguing and classification.

How to cite this paper: Ogunniyi, S.O. and Nwalo, K.I.N. (2016) Time Allocation as Correlate of Undergraduates' Academic Achievement in Cataloguing and Classification in Library Schools in Southern Nigeria. Open Access Library Journal, 3: e1915. http://dx.doi.org/10.4236/oalib.1101915 


\title{
Keywords
}

\author{
Time Allocation, Academic Achievement, Cataloguing and Classification, Library Schools, Southern \\ Nigeria
}

\author{
Subject Areas: Education
}

\section{Introduction}

In an educational setting, time is allocated for teaching and practical subjects/courses which require practical classes. Cataloguing and classification courses are expected to be taught theoretically and practically in library schools. Allison and Olugbade (2005) [1] citing Agabi and Olugbade (2010) stated that all school system activities were carried out within a time frame which might be limited to minutes, hours, days, months or even years. In educational institutions, time table is prepared to cover subjects/courses to be covered with allocated time and classrooms to be used for teaching. Edomwonyi-Otu and Avaa (2011) [2], in their study on the challenge of effective teaching of chemistry in some secondary schools in Zaria, Kaduna State, found that,

Time constraint is one of the major factors responsible for the poor performance of students. It is the reason why syllabus is not covered; science practicals are not conducted... The number of periods given to Chemistry per week and the time allocated for each lesson is usually not enough for effective learning because teacher cannot conduct any meaningful practical within the time limit.

The findings of Edomwonyi-Otu and Avaa's [2] are germane to the teaching and learning of cataloguing and classification in Nigerian library schools. Furthermore, subjects that are practical oriented like cataloguing should be allocated enough time for practical to ensure effective learning which will translate to high academic achievement of undergraduates in library schools. In the same vein, Reche, Bundi, Riungu and Mbugua (2012) [3] opine that the time allocated for teaching and learning is a factor influencing pupils' academic performance. In their research on the factors contributing to poor performance in Kenya Certificate of Primary Education in public day primary schools in Mwimbi Division, Maara District, Kenya, they discovered that most schools loosed many teaching/learning hours at the beginning of the term. This wastage leads to less work being covered and syllabi not being completed on time thereby contributing to poor performance in examinations. In view of the findings from Kenya and Zaria primary and secondary schools respectively, instructional time allocation is, therefore, a very important variable that may affect students' academic achievement in cataloguing in library schools.

\section{Statement of the Problem}

The main problem of this study is undergraduates' poor academic achievement in cataloguing and classification in library schools in Southern Nigeria. Cataloguing and classification are core courses in librarianship. Despite the importance of these courses in the library schools, it was observed that many undergraduates are known to have poor achievement in the examinations. Interaction with library educators and students revealed that undergraduates portray cataloguing as being difficult and were not able to have high score in cataloguing courses. This is a major concern of the literature on cataloguing and classification education. It has been observed also that some undergraduates in library schools, each year fail, to graduate because of poor performance in cataloguing courses. The poor academic achievement by undergraduates may be due to variety of causes. Undergraduates' academic achievement may be poor in cataloguing courses if time allocated for teaching and practicals is not adequate.

\section{Objectives of the Study}

The objectives of the study are to:

1) Identify the time allocated for teaching and learning cataloguing and classification in library schools in Southern Nigeria;

2) Find out the adequacy of the time allocated for teaching and practical cataloguing and classification in li- 
brary schools in Southern Nigeria, and

3) Find out the level of academic achievement of the undergraduates in cataloguing and classification in library schools in Southern Nigeria.

\section{Research Questions}

The following research questions were answered in this study:

1) How much time is allocated for teaching and learning cataloguing and classification in library schools in Southern Nigeria?

2) How adequate is the time allocated for teaching and practicals in cataloguing and classification in library schools in Southern Nigeria?

3) What is the level of academic achievement of the undergraduates in cataloguing and classification in library schools in Southern Nigeria?

\subsection{Hypothesis}

The hypothesis was tested at 0.05 level of significance.

HO1: There is no significant relationship between time allocation and academic achievement of undergraduates in cataloguing in library schools in Southern Nigeria.

\subsection{Literature Review}

Time allocation is one of the factors that may affect undergraduates' academic achievement in cataloguing in library schools. According to Lavy (2009) [4], while research in recent years provides convincing evidence about the effect of several inputs in the education production function, there is limited evidence on the effect of classroom instructional time. Instructional time allocation is being studied to find out whether the allocated time for a particular course is able to cover the course content or not. In a course of study like cataloguing and classification which is practical oriented, there is need to ascertain whether there is time for practicals. In cataloguing and classification teaching in the University of Pretoria, South Africa, De Boer, Coetzee and Coetzee (2001) [5] found that traditional content like cataloguing and reference work, are still taught although time allotted to them has been reduced. If the time allocated to teach a course like cataloguing and classification is short or reduced, it may have negative effect on the undergraduates' achievement in the courses.

$\mathrm{Li}$ (2005) [6] discovered that the practicum time for most of the courses surveyed for cataloguing and classification in China is too short to attain the goal to improve students' practical skills. In a paper presented in North American symposium on knowledge management titled "Teaching Cataloguing and Classification in $21^{\text {st }}$ Century”, Hudon (2011) [7] asserted that, in a majority of courses, instructors pay much lip service to bibliographic classification, to subject analysis, to DDC and LCC. Theory is allotted from one to five hours in 44 courses; this may be interpreted as time set aside to familiarise students with theoretical principles. Time allocated for teaching cataloguing and classification seems to be more on theory. Hudon [7] further stated that students do not appear to appreciate the principles and concepts; the younger students today seem to want the practical examples more than theories and principles. Although there is need for practical classes, cataloguing and classification theories and principles need to be known by students before practical can be employed.

Furthermore, Ocholla and Ocholla (2011) [8] discovered that one semester allocated for teaching cataloguing or classification is not adequate in South African library schools. Similarly, Ocholla, Ocholla, Olson, Glover and Guimaraes (2012) [9] discovered that time allotted for teaching cataloguing and classification in American and South African Library Schools is not enough. It was, therefore, recommended that concerted efforts should be made to correct the inadequacy of time allotted for teaching cataloguing and classification in the two library schools for students to have full grasp of the courses and have high academic achievement. Muthee (2012) suggested among other things that there should be allocation of more teaching and practical time to cataloguing and classification in the Kenyatta University library school in order to eradicate the cataloguing and classification problems. Furthermore, Nwalo (2005) [10] posited that there is insufficient lecture and practical periods in teaching cataloguing and classification courses in Nigerian library schools.

Concerning the teaching of other courses in Nigerian universities, Amori (2005) [11] found that the time allocated for teaching geography practical courses in some selected universities can be considered adequate. Con- 
trariwise, Jackden (2006) [12] discovered that the time allocated for teaching technical drawing lessons in Federal College of Education, Panshin is very inadequate. Jackden [12], citing Jackden and Okwori (1996) disclosed that time allocated for practicals and theory in many Colleges of Education in Nigeria is usually two to three hours; this is grossly insufficient. In another study on the challenge of effective teaching of Chemistry in some selected secondary schools in Zaria, Kaduna State, Edomwonyi-Otu and Avaa [2] found that 40 - 80 minutes allocated for teaching the subject is not enough. Since teachers are not able to complete their syllabus on the given time on the time table, it may affect the achievement of the students at the end of their programme in external examinations.

Ihebereme (2010) [13] asserted that the time allotment for computer lessons seems not to be enough for computer subject thus, the limited time may not allow enough opportunity for the teacher to teach, not to talk of imparting practical skills to the students. If there is no time to teach theory and practical in computer science, the pupils may not understand the subject and this may also lead to poor performance on the subjects at the end of the term. Similarly, Allison and Olugbade (1) discovered that the time frame for syllabus completion of Senior Secondary School mathematics in Rivers State is insufficient; this makes it impossible to complete subject syllabus and hence, students' preparation for external examinations is inadequate. The result of this is high rate of failure in external examinations.

Considering the instructional time allocation and students' academic achievement, Lavy (2009) [4] found that, from a sample of 15 year olds from over fifty countries that participated in Programme for International Student Assessment (PISA) in 2006 consistently shows that instructional time has a positive and significant effect on test scores. Furthermore, Jez and Wassmer (2011) [14] discovered that there is positive relationship between the number of instructional time in an academic year and school-site standardised test scores. Studies confirmed the relationship between time allocation and students' academic achievement. It is therefore necessary in a study like this to investigate whether there is a relationship between time allocated for cataloguing and undergraduates' academic achievement in library schools in Southern Nigeria.

\section{Methodology}

Survey research design of correlational type was adopted for this study. The final year undergraduates and lecturers teaching cataloguing and classification in library schools in Southern Nigeria were purposively selected for the study. Time allocated for teaching and learning cataloguing and classification scale $(a=0.64)$ and students' achievement test in cataloguing and classification $(a=0.63)$ were used to collect data for the study. Descriptive and inferential statistics were used for the data analysis. Descriptive and inferential statistics were used for the data analysis.

\subsection{Questionnaire Administration and Response Rate}

Table 1 showed that out of 550 questionnaire administered to the undergraduates in library schools in Southern Nigeria, 397 (72.2\%) were returned and found usable for analysis.

Table 2 showed that out of 18 copies of the questionnaire administered to the lecturers teaching cataloguing and classification in library schools in Southern Nigeria, 15 (83.3\%) were retrieved and found usable for the analysis.

\subsection{Demographic Information of Respondents}

This section focused on the demographic information of the respondents. Table 3 is the gender distribution of the undergraduates in library schools in Southern Nigeria.

Table 3 revealed that 257 (64.7\%) of the undergraduates respondents' are female while 140 (35.3\%) are male. The studies showed that majority of the respondents are female. Table 4 consists of rank, highest qualification, certificate in education and years of work experience of lecturers in library schools in Southern Nigeria.

Table 4 presents ranks, highest qualification, certificate in education and years of work experience of lecturers in library schools in Southern Nigeria.

Table 4 presents ranks, highest educational qualification, certificate in education and years of work experience of lecturers teaching cataloguing in library schools in Southern Nigeria. The highest group of respondents was the senior lecturer cadre 5 (33.3\%) while, the least group was an assistant lecturer 1 (6.7) and lecturer II 
Table 1. Undergraduates’ questionnaire distribution and response rate.

\begin{tabular}{|c|c|c|c|c|c|}
\hline $\mathrm{S} / \mathrm{N}$ & Name of Library School & No. Administered & No. Returned & $\begin{array}{l}\text { No. } \\
\text { Valid }\end{array}$ & Percent \\
\hline 1 & Abia State University, Uturu & 41 & 28 & 28 & 68.3 \\
\hline 2 & Delta State University, Abraka & 152 & 121 & 121 & 79.6 \\
\hline 3 & $\begin{array}{c}\text { Enugu State University of Science and Technology, } \\
\text { Agbani, Enugu }\end{array}$ & 20 & 11 & 11 & 55 \\
\hline 4 & Imo State University, Owerri & 79 & 43 & 43 & 54.4 \\
\hline 5 & Nnamdi Azikiwe University, Akwa & 45 & 38 & 38 & 84.4 \\
\hline 6 & Tai Solarin University of Education, Ijebu-Ode & 83 & 49 & 49 & 59 \\
\hline 7 & University of Ibadan, Ibadan & 60 & 51 & 51 & 83.3 \\
\hline 8 & University of Nigeria Nsukka & 43 & 35 & 35 & 81.4 \\
\hline \multirow[t]{2}{*}{9} & University of Uyo & 275 & 21 & 21 & 74.1 \\
\hline & Total & 550 & 397 & 397 & 72.0 \\
\hline
\end{tabular}

Table 2. Lecturers’ questionnaire distribution and response rate.

\begin{tabular}{|c|c|c|c|c|c|}
\hline $\mathrm{S} / \mathrm{N}$ & Name of Library School & No Administered & No Returned & No Valid & Percent \\
\hline 1 & Abia State University, Uturu & 3 & 2 & 2 & 66.7 \\
\hline 2 & Delta State University, Abraka & 2 & 2 & 2 & 100 \\
\hline 3 & $\begin{array}{c}\text { Enugu State University of Science and Technology, } \\
\text { Agbani, Enugu }\end{array}$ & 2 & 1 & 1 & 50.0 \\
\hline 4 & Imo State University, Owerri & 2 & 2 & 2 & 100.0 \\
\hline 5 & Nnamdi Azikiwe University, Akwa & 1 & 1 & 1 & 100.0 \\
\hline 6 & Tai Solarin University of Education, Ijebu-Ode & 3 & 2 & 2 & 66.7 \\
\hline 7 & University of Ibadan, Ibadan & 3 & 3 & 3 & 100.0 \\
\hline 8 & University of Nigeria Nsukka & 1 & 1 & 1 & 100.0 \\
\hline \multirow[t]{2}{*}{9} & University of Uyo & 1 & 1 & 1 & 100.0 \\
\hline & Total & 18 & 15 & 15 & 83.3 \\
\hline
\end{tabular}

Table 3. Gender distribution of the undergraduates.

\begin{tabular}{ccc}
\hline Gender & Frequency & Percentage \\
\hline Male & 140 & 35.3 \\
Female & 257 & 64.7 \\
Total & 397 & 100.0 \\
\hline
\end{tabular}

(6.7\%) cadres. Lecturers who hold the Ph.D 9 (60.0\%) were in the majority. Majority of the lecturers 8 (53.3\%) did not have any certificate in education. Teaching qualification is very important in teaching and learning processes. Findings reveal that, majority of the lecturers teaching cataloguing in library schools 14 (93.3\%) had considerably working experience (six years and above). However, most of the lecturers had no training in pedagogy.

\subsection{Answers to the Research Questions}

Research Question 1: How much time is allocated for teaching and learning cataloguing and classification in 
Table 4. Demographic variables of the lecturers teaching cataloguing.

\begin{tabular}{|c|c|c|c|}
\hline & Items & Frequency & Percentage \\
\hline \multirow{7}{*}{ Rank } & Assistant Lecturer & 1 & 6.7 \\
\hline & Lecturer 11 & 1 & 6.7 \\
\hline & Lecturer 1 & 3 & 20.0 \\
\hline & Senior Lecturer & 5 & 33.0 \\
\hline & Reader & 3 & 20.0 \\
\hline & Professor & 2 & 13.3 \\
\hline & & 15 & 100.0 \\
\hline \multirow{4}{*}{ Highest Qualification } & MLS/MLIS & 4 & 26.7 \\
\hline & MSC Inf Sc & 2 & 13.3 \\
\hline & Ph.D & 9 & 60.0 \\
\hline & & 15 & 100.0 \\
\hline \multirow{5}{*}{ Certificate in Education } & None & 8 & 53.3 \\
\hline & NCE & 1 & 6.7 \\
\hline & BED & 5 & 33.3 \\
\hline & MED & 1 & 6.7 \\
\hline & & 15 & 100.0 \\
\hline \multirow{6}{*}{ Years of Work Experience } & $0-5$ & 1 & 6.7 \\
\hline & $6-10$ & 1 & 6.7 \\
\hline & $11-15$ & 4 & 26.7 \\
\hline & $16-20$ & 5 & 33.3 \\
\hline & Above 20 & 4 & 26.7 \\
\hline & & 15 & 100.0 \\
\hline
\end{tabular}

library schools in Southern Nigeria?

The answer to this research question is presented in Table 5 .

Table 5 shows that, majority 323 (81.4\%) of the respondents stated that, two (2) hours per week was allocated on the time table for teaching cataloguing and classification. Some of the respondents 182 (45.8\%) also stated that no time was allocated for cataloguing practicals while 110 (27.7\%) indicated that 2 hours per week was allocated for cataloguing and classification practicals in the library schools in Southern Nigeria. It could be inferred from the finding that there is no specific time allocated on the time table for cataloguing practicals in library schools in Southern Nigeria.

Furthermore, the finding indicates that, majority of the lecturers $9(60 \%)$ stated that two (2) hours was allocated for teaching cataloguing. Other lecturers 7 (46.7\%) and 5 (33.3\%) selected 2 hours and no time was allocated for practical cataloguing and classification respectively. Additional information was given by two lecturers from Abia State University, Uturu and University of Ibadan library schools that the only two hours allocated for teaching cataloguing was being shared for theory and practicals that is, there is no specific time set aside for cataloguing practicals on the time table.

Research Question 2: What is the adequacy of the time allocated for teaching and practical cataloguing and classification in library schools in Southern Nigeria?

The result of the research question is presented in Table 6 .

Table 6 reveals that all course contents were covered during the teaching of cataloguing $\bar{X}=3.18$, SD $=$ 0.92. It was revealed that the time allocated for learning cataloguing was spent more on discussing the theory than practicals $\bar{X}=2.88, \mathrm{SD}=1.09$; extra time is needed for learning cataloguing in library school $\bar{X}=2.84$, $\mathrm{SD}=0.96$; lecturers are always in a hurry during lectures because of inadequacy of time allocated to teaching cataloguing $\bar{X}=2.69, \mathrm{SD}=1.03$; lecturers teaching cataloguing do not have time for practical $\bar{X}=2.52$, $\mathrm{SD}=$ 1.10 and number of semesters allocated for learning cataloguing is inadequate $\bar{X}=2.51, \mathrm{SD}=1.00$.

It may be inferred from the table that time allocated for learning cataloguing and classification in library schools in Southern Nigeria is partially adequate for theory but not adequate for practicals. The implication of the finding is that students are denied the practical aspect of cataloguing which is very important. There is need for theory to be balanced with practicals.

Lecturers' response on the adequacy of time allocated for teaching cataloguing is presented in Table 7.

Table 7 revealed that lecturers' teaching cataloguing stated that all the course contents were covered $\bar{X}=$ 
Table 5. Students' response on the time allocated on the time table in teaching and practical cataloguing.

\begin{tabular}{|c|c|c|c|c|}
\hline $\mathrm{S} / \mathrm{N}$ & Items & Hours Allocated & Frequency & Percentage \\
\hline 1 & $\begin{array}{l}\text { No. of hour(s) allocated on the time table for teaching } \\
\text { cataloguing and classification in library schools. }\end{array}$ & $\begin{array}{c}2 \text { hours per week } \\
3 \text { hours per week } \\
4 \text { hours } \\
\text { Others (1 hour per week) }\end{array}$ & $\begin{array}{c}323 \\
39 \\
24 \\
11 \\
397\end{array}$ & $\begin{array}{c}81.4 \\
9.8 \\
6.0 \\
2.8 \\
100.0\end{array}$ \\
\hline 2 & $\begin{array}{l}\text { No. of hour(s) allocated on the time table for practical } \\
\text { cataloguing and classification in library schools. }\end{array}$ & $\begin{array}{c}0 \text { hour per week } \\
1 \text { hours per week } \\
2 \text { hours per week } \\
3 \text { hours per week } \\
4 \text { hours per week } \\
\text { Others ( } 5 \text { hours per week) }\end{array}$ & $\begin{array}{c}182 \\
54 \\
110 \\
28 \\
18 \\
5 \\
397\end{array}$ & $\begin{array}{c}45.8 \\
13.6 \\
27.7 \\
7.0 \\
4.5 \\
1.2 \\
99.8\end{array}$ \\
\hline
\end{tabular}

Table 6. Undergraduates' response on adequacy of time allocated in learning cataloguing in library schools in southern Nigeria.

\begin{tabular}{|c|c|c|c|c|c|c|c|}
\hline $\mathrm{S} / \mathrm{N}$ & Items & SD & D & A & SA & Mean & S.D. \\
\hline 1 & $\begin{array}{l}\text { All course contents are covered during cataloguing } \\
\text { teaching. }\end{array}$ & $\begin{array}{c}28 \\
7.1 \%\end{array}$ & $\begin{array}{c}55 \\
13.9 \%\end{array}$ & $\begin{array}{c}133 \\
33.5 \%\end{array}$ & $\begin{array}{c}181 \\
45.6 \%\end{array}$ & 3.18 & 0.92 \\
\hline 2 & $\begin{array}{l}\text { Time allocated for learning cataloguing is more on } \\
\text { theory than practical. }\end{array}$ & $\begin{array}{c}64 \\
16.1 \%\end{array}$ & $\begin{array}{c}69 \\
17.4 \%\end{array}$ & $\begin{array}{c}114 \\
28.7 \%\end{array}$ & $\begin{array}{c}150 \\
37.8 \%\end{array}$ & 2.88 & 1.09 \\
\hline 3 & $\begin{array}{l}\text { Extra time is needed for learning cataloguing in our } \\
\text { library school. }\end{array}$ & $\begin{array}{c}51 \\
12.8 \%\end{array}$ & $\begin{array}{c}66 \\
16.6 \%\end{array}$ & $\begin{array}{c}176 \\
44.3 \%\end{array}$ & $\begin{array}{c}104 \\
26.2 \%\end{array}$ & 2.84 & 0.96 \\
\hline 4 & $\begin{array}{l}\text { Lecturers are always in a hurry during lectures } \\
\text { because of inadequacy of time allotted for teaching } \\
\text { cataloguing. }\end{array}$ & $\begin{array}{c}69 \\
17.4 \%\end{array}$ & $\begin{array}{c}84 \\
21.2 \%\end{array}$ & $\begin{array}{c}144 \\
36.3 \%\end{array}$ & $\begin{array}{c}100 \\
25.2 \%\end{array}$ & 2.69 & 1.03 \\
\hline 5 & $\begin{array}{l}\text { Lecturers teaching cataloguing and classification do } \\
\text { not have time for practicals }\end{array}$ & $\begin{array}{c}93 \\
23.4 \%\end{array}$ & $\begin{array}{c}101 \\
25.4 \%\end{array}$ & $\begin{array}{c}106 \\
26.7 \%\end{array}$ & $\begin{array}{c}97 \\
24.4 \%\end{array}$ & 2.52 & 1.10 \\
\hline 6 & $\begin{array}{l}\text { Number of semesters allocated for learning } \\
\text { cataloguing and classification is inadequate }\end{array}$ & $\begin{array}{c}75 \\
18.9 \%\end{array}$ & $\begin{array}{c}119 \\
30.0 \%\end{array}$ & $\begin{array}{c}129 \\
32.5 \%\end{array}$ & $\begin{array}{c}74 \\
18.6 \%\end{array}$ & 2.51 & 1.00 \\
\hline 7 & $\begin{array}{l}\text { Time allocated for learning cataloguing and } \\
\text { classification in our library school is enough. }\end{array}$ & $\begin{array}{c}80 \\
20.2 \%\end{array}$ & $\begin{array}{c}131 \\
33.0 \%\end{array}$ & $\begin{array}{c}110 \\
27.7 \%\end{array}$ & $\begin{array}{c}76 \\
19.1 \%\end{array}$ & 2.46 & 1.02 \\
\hline 8 & $\begin{array}{l}\text { Time allocated for learning cataloguing and } \\
\text { classification is not sufficient }\end{array}$ & $\begin{array}{c}89 \\
22.4 \%\end{array}$ & $\begin{array}{c}119 \\
30.0 \%\end{array}$ & $\begin{array}{c}111 \\
28.0 \%\end{array}$ & $\begin{array}{c}78 \\
19.6 \%\end{array}$ & 2.45 & 1.04 \\
\hline 9 & $\begin{array}{l}\text { Practical class for cataloguing and classification is } \\
\text { not encouraged in our library school }\end{array}$ & $\begin{array}{c}106 \\
26.7 \%\end{array}$ & $\begin{array}{c}98 \\
24.7 \%\end{array}$ & $\begin{array}{c}106 \\
26.7 \%\end{array}$ & $\begin{array}{c}87 \\
21.9 \%\end{array}$ & 2.44 & 1.11 \\
\hline 10 & $\begin{array}{l}\text { Lecturers always advise us to read aspects of } \\
\text { cataloguing and classification not taught in class. }\end{array}$ & $\begin{array}{c}73 \\
18.4 \%\end{array}$ & $\begin{array}{c}168 \\
42.3 \%\end{array}$ & $\begin{array}{c}83 \\
20.9 \%\end{array}$ & $\begin{array}{c}73 \\
18.4 \%\end{array}$ & 2.39 & 0.99 \\
\hline 11 & $\begin{array}{l}\text { There is no time for cataloguing and classification } \\
\text { practicals in our library school. }\end{array}$ & $\begin{array}{c}110 \\
27.7 \%\end{array}$ & $\begin{array}{c}105 \\
26.4 \%\end{array}$ & $\begin{array}{c}104 \\
26.2 \%\end{array}$ & $\begin{array}{c}78 \\
19.6 \%\end{array}$ & 2.38 & 1.09 \\
\hline 12 & $\begin{array}{l}\text { Number of periods allocated for cataloguing and } \\
\text { classification practical at the end of semester is } \\
\text { enough in our library school. }\end{array}$ & $\begin{array}{c}98 \\
24.7 \%\end{array}$ & $\begin{array}{c}122 \\
30.7 \%\end{array}$ & $\begin{array}{c}112 \\
28.2 \%\end{array}$ & $\begin{array}{c}65 \\
16.4 \%\end{array}$ & 2.36 & 1.03 \\
\hline 13 & $\begin{array}{l}\text { There is not enough time to cover all the rules and } \\
\text { principles of cataloguing and classification during } \\
\text { practicals. }\end{array}$ & $\begin{array}{c}128 \\
32.2 \%\end{array}$ & $\begin{array}{c}138 \\
34.8 \%\end{array}$ & $\begin{array}{c}69 \\
17.4 \%\end{array}$ & $\begin{array}{c}62 \\
15.6 \%\end{array}$ & 2.16 & 1.05 \\
\hline
\end{tabular}

3.07, $\mathrm{SD}=0.96$; number of semesters allocated for teaching cataloguing was sufficient $\bar{X}=2.73$, SD $=1.10$; time allocated for teaching cataloguing and classification was enough in their library school $\bar{X}=2.53$, SD = 1.06. It may be noted that though the lecturers claimed sufficiency of time allocated for teaching cataloguing, 
Table 7. Lecturers' response on adequacy of time allocated in teaching cataloguing in library schools.

\begin{tabular}{|c|c|c|c|c|c|c|c|}
\hline $\mathrm{S} / \mathrm{N}$ & Items & SD & D & A & SA & Mean & S.D. \\
\hline 1 & $\begin{array}{l}\text { All course contents are covered during cataloguing } \\
\text { teaching. }\end{array}$ & $\begin{array}{c}1 \\
6.7 \%\end{array}$ & $\begin{array}{c}3 \\
20.0 \%\end{array}$ & $\begin{array}{c}5 \\
33.3 \%\end{array}$ & $\begin{array}{c}6 \\
40.0 \%\end{array}$ & 3.07 & 0.96 \\
\hline 2 & $\begin{array}{l}\text { Number of semesters allocated for teaching cataloguing } \\
\text { and classification is sufficient. }\end{array}$ & $\begin{array}{c}3 \\
20.0 \%\end{array}$ & $\begin{array}{c}2 \\
13.3 \%\end{array}$ & $\begin{array}{c}6 \\
40.0 \%\end{array}$ & $\begin{array}{c}4 \\
26.7 \%\end{array}$ & 2.73 & 1.10 \\
\hline 3 & $\begin{array}{l}\text { Time allocated for teaching cataloguing and classification } \\
\text { is not sufficient }\end{array}$ & $\begin{array}{c}3 \\
20.0 \%\end{array}$ & $\begin{array}{c}3 \\
20.0 \%\end{array}$ & $\begin{array}{c}5 \\
33.3 \%\end{array}$ & $\begin{array}{c}4 \\
26.7 \%\end{array}$ & 2.67 & 1.11 \\
\hline 4 & $\begin{array}{l}\text { I always instruct students to read uncovered cataloguing } \\
\text { and classification course contents because time allocated } \\
\text { to it is inadequate. }\end{array}$ & $\begin{array}{c}3 \\
20.0 \%\end{array}$ & $\begin{array}{c}3 \\
20.0 \%\end{array}$ & $\begin{array}{c}6 \\
40.0 \%\end{array}$ & $\begin{array}{c}3 \\
20.0 \%\end{array}$ & 2.60 & 1.06 \\
\hline 5 & $\begin{array}{l}\text { Time allocated for teaching cataloguing and classification } \\
\text { is enough in our library school. }\end{array}$ & $\begin{array}{c}3 \\
20.0 \%\end{array}$ & $\begin{array}{c}4 \\
26.7 \%\end{array}$ & $\begin{array}{c}5 \\
33.3 \%\end{array}$ & $\begin{array}{c}3 \\
20.0 \%\end{array}$ & 2.53 & 1.06 \\
\hline 6 & $\begin{array}{l}\text { I don't have enough time to cover all the rules and } \\
\text { principles of cataloguing and classification during } \\
\text { practical }\end{array}$ & $\begin{array}{c}3 \\
20.0 \%\end{array}$ & $\begin{array}{c}5 \\
33.3 \%\end{array}$ & $\begin{array}{c}4 \\
26.7 \%\end{array}$ & $\begin{array}{c}3 \\
20.0 \%\end{array}$ & 2.47 & 1.06 \\
\hline 7 & $\begin{array}{l}\text { Number of periods allocated for cataloguing and } \\
\text { classification practical is adequate for practical skills }\end{array}$ & $\begin{array}{c}6 \\
40.0 \%\end{array}$ & $\begin{array}{c}2 \\
13.3 \%\end{array}$ & $\begin{array}{c}3 \\
20.0 \%\end{array}$ & $\begin{array}{c}4 \\
26.7 \%\end{array}$ & 2.33 & 1.29 \\
\hline 8 & $\begin{array}{l}\text { Extra time is not needed for teaching cataloguing in our } \\
\text { library and information science school. }\end{array}$ & $\begin{array}{c}4 \\
26.7 \%\end{array}$ & $\begin{array}{c}4 \\
26.7 \%\end{array}$ & $\begin{array}{c}6 \\
40.0 \%\end{array}$ & $\begin{array}{c}1 \\
6.7 \%\end{array}$ & 2.27 & 0.96 \\
\hline 9 & $\begin{array}{l}\text { I am always in a hurry during lectures because of } \\
\text { inadequacy of time allocated for teaching cataloguing } \\
\text { and cl }{ }^{\mathbb{B}} \text { ssification. }\end{array}$ & $\begin{array}{c}3 \\
20.0 \%\end{array}$ & $\begin{array}{c}7 \\
46.7 \%\end{array}$ & $\begin{array}{c}3 \\
20.0 \%\end{array}$ & $\begin{array}{c}2 \\
13.3 \%\end{array}$ & 2.27 & 0.96 \\
\hline 10 & $\begin{array}{l}\text { I spent more time on teaching theory and principles of } \\
\text { cataloguing and classification and very little for practical }\end{array}$ & $\begin{array}{c}3 \\
20.0 \%\end{array}$ & $\begin{array}{c}6 \\
40.0 \%\end{array}$ & $\begin{array}{c}5 \\
33.3 \%\end{array}$ & $\begin{array}{c}1 \\
6.7 \%\end{array}$ & 2.27 & 0.88 \\
\hline 11 & $\begin{array}{l}\text { Practical class for cataloguing and classification is not } \\
\text { encouraged in our library school }\end{array}$ & $\begin{array}{c}7 \\
46.7 \%\end{array}$ & $\begin{array}{c}3 \\
20.0 \%\end{array}$ & $\begin{array}{c}4 \\
26.7 \%\end{array}$ & $\begin{array}{c}1 \\
6.7 \%\end{array}$ & 1.93 & 1.03 \\
\hline 12 & $\begin{array}{l}\text { There is no time for cataloguing and classification } \\
\text { practical in our library school }\end{array}$ & $\begin{array}{c}7 \\
46.7 \%\end{array}$ & $\begin{array}{c}6 \\
40.0 \%\end{array}$ & $\begin{array}{c}2 \\
13.3 \%\end{array}$ & - & 1.67 & 0.72 \\
\hline 13 & $\begin{array}{l}\text { I don't have time for practical cataloguing and } \\
\text { classification. }\end{array}$ & $\begin{array}{c}8 \\
53.3 \%\end{array}$ & $\begin{array}{c}5 \\
33.3 \%\end{array}$ & $\begin{array}{c}2 \\
13.3 \%\end{array}$ & - & 1.60 & 0.74 \\
\hline
\end{tabular}

but it was revealed from their responses that generally, time allocated for teaching cataloguing and classification was inadequate $\bar{X}=2.67, \mathrm{SD}=1.06$ and lecturers always instruct students to read uncovered cataloguing and classification content because time allocated to it was inadequate $\bar{X}=2.60, \mathrm{SD}=1.06$. It could be inferred that time allocated for teaching cataloguing was inadequate.

Research Question 3: What is the level of academic achievement of the undergraduates in cataloguing and

classification in library schools in Southern Nigeria?

The answer to the research question is presented in Table 8.

Table 8 shows that, majority of the respondents' academic achievement in cataloguing was average 261 (65.7\%).

HO1: There is no significant relationship between time allocation and academic achievement of undergraduates in cataloguing in library schools in Southern Nigeria.

The result of hypothesis 1 is presented in Table 9.

Table 9 indicated that there was positive and weak relationship between time allocation and academic achievement of undergraduates in cataloguing $\left(r=0.377^{* *}, \mathrm{df}=395, \mathrm{P}<0.05\right)$. This relationship was significant therefore, the null hypothesis is rejected.

\section{Discussion of the Findings}

Finding showed that there was no specific time allocated for cataloguing practicals on the time table. The two (2) hours allocated for the course was shared for teaching and practicals by lecturers. The finding is in agreement with Nwalo [10] that there is insufficient lecture and practical periods in teaching and learning cataloguing and classification courses in Nigerian library schools. There should be a concerted effort by heads of library and 
Table 8. Academic achievement of undergraduates in cataloguing.

\begin{tabular}{ccc}
\hline Achievement & Frequency & Percentage \\
\hline Low $(0-19)$ & 117 & 29.4 \\
Average $(20$ - 34) & 261 & 65.7 \\
High (35 and above) & 19 & 4.8 \\
Total & 397 & 100.0 \\
\hline
\end{tabular}

Table 9. Relationship between time allocation and undergraduates achievement in cataloguing.

\begin{tabular}{cccccccc}
\hline Variable & N & .Mean & Std. Dev. & Df & r & P & Remark \\
\hline Time Allocation & 397 & 36.2544 & 8.7714 & & & & \\
Academic Achievement & 397 & 23.8942 & 6.8279 & \multirow{2}{*}{395} & $0.377^{* *}$ & 0.000 & Sig. \\
\hline
\end{tabular}

*Sig. at 0.05 level.

information science schools in Nigeria in allocating separate time on the time table for cataloguing teaching and practical. The finding is in accordance with those of Ocholla, Ocholla, Olson, Glover and Guimaraes [9] that time allotted for cataloguing and classification in American and South African Library Schools was not enough. The problem of inadequate time allocation in teaching and learning cataloguing appears to be global but needs a solution for better performance of the undergraduates.

The finding of the study revealed relationship between time allocation and academic achievement of undergraduates in cataloguing in library schools. The relationship is strong, positive and significant. The implication of this study is that adequate time allocation for teaching and learning cataloguing is very essential for enhancing performance of undergraduates in the library schools. The finding of this study is in congruent with Lavy [4] discovery from a sample of 15 years old from over fifty countries that participated in Programme for International Assessment (PISA) in 2006 consistently shows that instructional time has a positive and significant effect on test scores. Furthermore, the finding corroborates those of Jez and Wassmer [14] who established that there is positive relationship between the number of instructional time in an academic year and students' performance. In the same vein, the finding of this study is in agreement with Reche, Bundi, Riungu and Mbugua [3] that the time allocated for teaching and learning is a factor influencing pupils' academic performance in Primary Schools in Mwimbi Division, Maara District, Kenya.

\section{Conclusion}

The finding of the study revealed significant relationship between time allocation and academic achievement of undergraduates in cataloguing and classification in library schools. Time allocated for teaching cataloguing and classification was inadequate. Academic achievement of the undergraduates was average.

\section{Recommendations}

In view of the findings from the study, the following recommendations are made to improve undergraduates' academic achievement in cataloguing in library schools in Nigeria:

1) The study revealed that there was no specific time allocated for cataloguing practicals, the library school management in partnership with the National Universities Commission (NUC) should include separate hour on the time table for practical cataloguing and classification in library schools in Nigeria to enable students to balance theory with practical knowledge. This is necessary to enhance students' academic achievement in cataloguing and classification.

2) Lecturers teaching cataloguing and classification should spend more time in cataloguing practicals to encourage the students to develop interest in cataloguing and classification courses.

\section{References}

[1] Allison, D.S. and Olugbade, O.D. (2005) Time Frame and Syllabus Completion of Senior Secondary Mathematics in 
Omoku, Nigeria. Mediterranean Journal of Social Sciences, 2, 3.

[2] Edomwonyi-Otu, L. and Avaa, A. (2011) The Challenge of Effective Teaching of Chemistry: A Case Study. http://lejpt.academicdirect.org/A18/001_008.htm

[3] Reche, G.N. Bundi, T.K., Riungu, J.N. and Mbugua, Z.K. (2015) Factors Contributing to Poor Performance in Kenya Certificate of Primary Education in Public Day Primary Schools in Mwimbi Division, Maara District, Kenya. International Journal of Humanities and Social Science, 2, 129.

[4] Lavy, V. (2009) The Effect of Instructional Time on Achievements in Math, Science and Reading: Evidence from Developed Countries. Department of Economics, University of London, London.

[5] De-Boer, A., Coetzee, H.S. and Coetzee, H. (2001) Teaching Cataloguing and Classification at the University of Pretoria: Thinking Preferences of Second Year Students. Libri, 51, 20-30. http://dx.doi.org/10.1515/LIBR.2001.114

[6] Li, S. (2005) The Status Quo and Future Development of Cataloguing and Classification Education in China. http://www.haworthpress.com/web/CCQ

[7] Hudon, M. (2011) Teaching Cataloguing and Classification in $21^{\text {st }}$ Century. Proceeding of Paper Presented at the North American Symposium on Knowledge Organization, Toronto, 63-73.

[8] Ocholla, L. and Ocholla, D.N. (2011) Cataloguing and Classification Education and Training in Library and Information Science/Studies Departments in South Africa. The 18th International Conference on Libraries and Information Resources in the Modern World of Science, Culture, Education and Business, Crimea.

[9] Ocholla, D.N., Ocholla, L., Olson, H.A. Glover, J.R. and Guimaraes, J.A. (2012) Cataloguing and Classification Education and Training in Library and Information Science/Studies in South Africa, Brazil and USA. http://conference.ifla.org/ifla78

[10] Nwalo, K.I.N. (2005) The 21st Century Cataloguer: Challenges of Education and Training in Nigeria. In: Lasisi, J., Odusanya, O.K., Sonaike, S.E.A., Okegbola, E.O., Balogun, F.O., Osinulu, L.F. and Akidi, J.O., Eds., Proceedings of Selected Seminar Paper of the Cataloguing, Classification and Indexing Section of the Nigerian Library Association 1995-2000, NLA/CCI, Lagos.

[11] Amori, A.A. (2005) Resource Provision and Utilisation, Mathematical Ability and Learning Environment as Predictors of Learning Outcomes in Undergraduate Practical Geography Courses. Ph.D. Thesis, Department of Teacher Education, University of Ibadan, Ibadan, $334 \mathrm{p}$.

[12] Jackden, H.N. (2006) Effectiveness of Methods in Teaching Technical Drawing in Federal College of Education, Panshin, Nigeria. International Journal of Research in Education, 3, 105-106.

[13] Ihebereme, C.I. (2010) Teaching of Computer Science Education in Primary Schools. A Computer Education for Sustainable Development. In: Atinmo, M.I., Babalola, J.B., Moronkola, O.A. and Atanda, A.I., Eds., Faculty of Education, University of Ibadan, Ibadan, 131.

[14] Jez, S.J. and Wassmer, R.W. (2011) The Impact of Learning Time on Academic Achievement. Faculty Fellow Research Programs, Center for California Studies, California State University, Sacramento. 